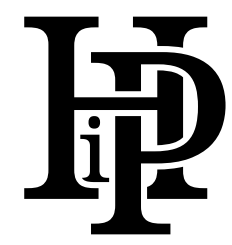

Historia i Polityka

$\mathrm{Nr} 37(44) / 2021$, pp. 159-163

www.hip.umk.pl @® $\Theta$

ISSN 1899-5160, e-ISSN 2391-7652

DOI: http://dx.doi.org/10.12775/HiP.2021.030

Sylwia GROCHOWINA

Uniwersytet Mikołaja Kopernika, Wydział Nauk Historycznych, Toruń, Polska

\title{
Mein Kampf. Moja walka. Edycja krytyczna, z języka niemieckiego przełożył, wstępem, przypisami i bibliografią selektywną opatrzył Eugeniusz Cezary Król, Bellona, Warszawa 2020, ss. 1000
}

Z pewnością nie jest przesadne stwierdzenie, że Mein Kampf autorstwa Adolfa Hitlera to jedna z najbardziej kontrowersyjnych książek w dziejach ludzkości. Jej istotą jest światopogląd narodowosocjalistyczny, który przywołuje oczywiste skojarzenia z wybuchem II wojny światowej i licznymi zbrodniami popełnionymi przez nazistów.

W styczniu 2016 roku dzięki kilkuletniej pracy zespołu historyków z Instytutu Historii Najnowszej (Institut für Zeitgeschichte) w Monachium ukazała się niemiecka krytyczna edycja Mein Kampf (2016). Z kolei w styczniu 2021 roku nakładem wydawnictwa „Bellona” krytyczne wydanie Mein Kampf trafiło do rąk polskiego czytelnika. Autorem przekładu i opracowania naukowego, liczącego 836 stron, jest profesor Eugeniusz Cezary Król - historyk i politolog, wybitny znawca dziejów Trzeciej Rzeszy i narodowego socjalizmu, tłumacz niemieckiej literatury historycznej, autor m.in. krytycznego wydania wyboru dzienników Josepha Goebbelsa (2014). Dlaczego profesor zdecydo- wał się na przygotowanie krytycznej edycji Mein Kampf? Czy dzieło Hitlera zasługuje na rozpowszechnianie? W kontekście tych pytań warto zwrócić uwagę na motto zamieszczone na początku książki: „Pamięci ofiar zbrodniczego systemu, ku przestrodze kolejnym pokoleniom".

W pierwszej części wstępu zatytułowanego „Hitler i jego walka” profesor Król przybliża czytelnikowi okoliczności powstania Mein Kampf, co idzie w parze z przedstawieniem kariery politycznej jej autora. Po nieudanym puczu monachijskim z 8 listopada 1923 roku Hitler został skazany na pięć lat więzienia w twierdzy Landsberg. Wykorzystując dobre warunki odbywania kary, za namową odwiedzających go gości, postanowił napisać polityczną autobiografię, a jej tekst dyktował swoim sekretarzom - najpierw kierowcy Emilowi Maurice'owi, a następnie Rudolfowi Hessowi. $Z$ inicjatywy wydawcy Maxa Amanna zmieniono pierwotny tytuł, który brzmiał Viereinhalb Jahre gegen Lüge, Dummheit und Freigheit (Cztery i pół roku walki z kłam- 
stwami, głupotą i tchórzostwem). Nowy, znacznie krótszy i bardziej rzeczowy tytuł Mein Kampf miał przyciągnąć uwage potencjalnych czytelników i przynieść korzyści komercyjne. Pierwszy tom dzieła Hitlera ukazał się w lipcu 1925, drugi zaś w grudniu 1926 roku z podtytułem Die nationalsozialistische Bewegung (Ruch narodowosocjalistyczny). W 1930 roku oba tomy zostały połączone w jeden, a jego kieszonkowy format i charakterystyczna ciemna okładka sprawiły, że przypominał Biblię. Chcąc wyjaśnić czytelnikowi, czym jest Mein Kampf, profesor Król podkreśla, że „nie należy przydawać jej jakichś walorów religijnych czy też mistycznych" [s. 12]. Książka ta składa się z dwóch części: część pierwsza zatytułowana „Rozrachunek” to propagandowa wersja autobiografii jej autora, a w części drugiej zatytułowanej „Ruch narodowosocjalistyczny" autor nakreślił program polityczny i wskazał metody, jakimi narodowi socjaliści muszą się posługiwać, by zdobyć i utrzymać władzę. Hitler obiecywał swoim rodakom rozwiązanie bieżących problemów, w tym przede wszystkim: zmazanie tzw. wersalskiej hańby, stworzenie „wspólnoty narodowej" (Volksgemeinschaft) wolnej od osób nieodpowiednich ze względów rasowych i politycznych, która miała urzeczywistnić ideę zdobycia „przestrzeni życiowej” (Lebensraum) na Wschodzie i wskrzeszenia silnego państwa niemieckiego. Mein $K a m p f$, jak wskazuje autor polskiego przekładu, było czymś, z czym miał się identyfikować przeciętny Niemiec: „To wszystko dla przeciętnego Niemca $z$ lat dwudziestych $\mathrm{XX}$ wieku, zgnębionego prozą codziennego życia, mogło być przekonujące, a nawet imponujące” [s. 32]. We wstępie profesor Król odnotowuje także, że niewiele uwagi Hitler poświęcił w Mein Kampf Polsce: „Zdawkowość sformułowań dotyczących problematyki Polski i Polaków wynikała z jednej strony z braku dostatecznej orientacji autora, z drugiej jednak z jego przekonania, że sprawy polskie nie stanowią kwestii o znaczeniu pierwszoplanowym" [s. 25-26].

Po pobieżnym przeglądzie zawartości Mein Kampf profesor Król zwraca uwagę na właściwości literackie tej książki: „Duże fragmenty Mein Kampf przypominają bardziej konspekt przemówienia aniżeli tekst pisany [...]. Występują kompozycje słów z cechami neologizmów, ma miejsce skłonność do słowotoku, do »talmudycznej« metody stawiania natrętnych pytań, do upartego, bez wyraźnej potrzeby używania tych samych słów, takich jak "także», "ciągle», "znowu«, "jednak". Często pojawia się powtórzenie, dublowanie synonimów, dramatyzujące stopniowanie przymiotników i przysłówków, dowolne traktowanie szyku zdań” [s. 29-30].

W kolejnej części wstępu profesor Król analizuje recepcję Mein Kampf zarówno w Niemczech, jak i za granicą. Po przejęciu władzy naziści uruchomili potężną machinę propagandową do promowania dzieła Hitlera i podjęli konkretne działania, które sprawiły, że do końca istnienia Trzeciej Rzeszy rozprowadzono około 12450000 egzemplarzy Mein Kampf, co przyniosło autorowi tej książki duży sukces finansowy. Profesor Król słusznie stawia pytanie: „Jaka część astronomicznego nakładu Mein Kampf dotarła do Niemców i została przez nich rzeczywiście przeczytana?" [s. 34]. Trudno jednak o obiektywne i konkretne dane w tej sprawie, więc nie sposób jednoznacznie rozstrzygnąć, jaki był rzeczywisty odbiór tej książki. Faktem jest jednak, że dzięki bardzo sprawnie działającemu aparatowi propagandy Niemcy doskonale znali idee zawarte w dziele Hitlera, tym bardziej że istniało wiele streszczeń „nazistowskiej biblii”, które rozprowadzano w formie różnorakich broszur, szeroko wykorzystywa- 
nych przez nazistów w procesie indoktrynacji. Profesor Król odnotowuje również, że „nie brakowało też wyrazów protestu, pochodzących przede wszystkim od twórców kultury, publicystów i pisarzy o orientacji socjaldemokratycznej, komunistycznej, liberalnej i katolickiej” [s. 35], a jako „wyrazisty przypadek w tym względzie” wskazuje postawę braci Mannów - Tomasza i Henryka. Pierwszy z nich, laureat Literackiej Nagrody Nobla w 1929 roku, określił tę książkę mianem „volkistowskiego pogaństwa” (völkisches Heidentum) i „romantycznego barbarzyństwa” (romantische Barbarei). Niestety, jak pisze profesor Król: „zawartość Mein Kampf nie spotkała się ze zdecydowanym i gremialnym odporem niemieckich środowisk opiniotwórczych" [s. 37]. Nie tylko Niemcy mieli możliwość zapoznania się z dziełem Hitlera, lecz robiło ono również „karierę” międzynarodową. Hitler nie chciał jednak, aby jego książka wychodziła poza granice Niemiec w sposób niekontrolowany i w związku z tym tłumaczenia musiały być ocenzurowane w zależności od kraju przeznaczenia. Zazwyczaj zagraniczne wydania Mein Kampf ukazywały się w wersji okrojonej (uszczuplenia tekstu dotyczyły zwłaszcza koncepcji i planów związanych z polityką zagraniczną). Do 1945 roku dzieło Hitlera wydano m.in. w Brazylii, Chinach, Danii, Finlandii, Francji, Hiszpanii, Holandii, Japonii, Norwegii, Szwecji, Stanach Zjednoczonych, Wielkiej Brytanii i we Włoszech, a czytali je zarówno zwykli obywatele, jak i wielcy politycy. Prezentując światową karierę Mein Kampf, profesor Król zastanawia się, czy czytelnicy tej książki widzieli zawarte w niej zagrożenie. Odpowiedź na to pytanie jest niestety bardzo przygnębiająca: „Wielomilionowe nakłady w Niemczech, wielusettysięczne nakłady tłumaczeń, niewątpliwie szeroki zakres czytelnictwa - wszystko to nie po- zwoliło wytrawnym politykom, dziennikarzom, przedstawicielom elit kulturalnych, wreszcie zwykłym obywatelom różnych krajów rozpoznać i należycie ocenić grozę wyzierającą ze stron Mein Kampf. Pomijając raczej odosobnione sygnały alarmu, rozlegające się w Niemczech i innych krajach europejskich, nie udało się w porę zażegnać niebezpieczeństwa, uchwycić iunctim między słowami i czynami. Triumfowała postawa bagatelizacji, a potem przekonanie o możliwości przejęcia kontroli i zapanowania nad niebezpiecznymi rojeniami niezrównoważonego, ale też, wydawało się, nieszkodliwego fanatyka” [s. 53].

W dalszej części narracji profesor Król przedstawia powojenną "karierę" Mein Kampf. Chociaż w Niemczech i w wielu innych krajach książka ta znalazła się na „indeksie ksiąg zakazanych", to jednak nadal funkcjonowała w tzw. drugim obiegu. W październiku 1948 roku, na podstawie wyroku sądu w Monachium o konfiskacie mienia należącego do Hitlera, prawa autorskie do Mein Kampf alianci przekazali krajowi związkowemu Bawaria. Od tego czasu władze Bawarii konsekwentnie odmawiały zgody na publikowanie Mein Kampfi z tytułu naruszenia praw autorskich ścigały nielegalnych wydawców dzieła Hitlera. Jako że ochrona prawna każdego dzieła wygasa po 70 latach od śmierci autora, w 2015 roku Mein Kampf stała się częścią domeny publicznej.

Po krótkiej charakterystyce krytycznej edycji Mein Kampf przygotowanej przez Instytut Historii Najnowszej w Monachium i opublikowanej w styczniu 2016 roku, profesor Król sformułował argumenty, które skłoniły go do przetłumaczenia Mein $K a m p f$ z języka niemieckiego na język polski i przygotowania edycji krytycznej tej książki. W jego opinii Mein Kampf „oprócz licznych mielizn, mieszczących w sobie męt- 
ne, pseudonaukowe wywody autora, zawiera też fragmenty, które nadal należy czytać z uwagą. Chodzi tu zwłaszcza o budowanie konstrukcji »śmiertelnego« i »odwiecznego» wroga, rolę propagandy $\mathrm{w}$ procesie masowego oddziaływania politycznego, a także kształtowanie podstaw hitlerowskiej geopolityki (zdobywanie "przestrzeni życiowej«, kreowanie systemu sojuszy)” [s. 65]. Nie sposób nie zgodzić się z tymi słowami, tym bardziej że profesor Król jest znawcą nazistowskiej propagandy, której poświęcił imponujące książki: Propaganda $i$ indoktrynacja narodowego socjalizmu $w$ Niemczech 1919-1945. Studium organizacji, treści, metod $i$ technik masowego oddziaływania oraz Polska i Polacy $w$ propagandzie narodowego socjalizmu $w$ Niemczech 1919-1945. Zgodnie $\mathrm{z}$ intencjami wskazanymi przez autora polskiego przekładu i opracowania naukowego przygotowana publikacja ma ograniczyć zasięg niekompletnych i pozbawionych aparatu naukowego/krytycznego przekładów książki Hitlera, głównie z języka angielskiego [sic!], dostępnych zarówno w Internecie, jak i w wersjach papierowych. Poza tym edycja krytyczna Mein Kampf ma odmitologizować tę książkę i pozbawić ją statusu „owocu zakazanego”, budzącego niezdrową sensację. Rozwijając motto zamieszczone na początku książki, profesor Król pisze: „Należy widzieć w autorskiej, krytycznej edycji książki Hitlera wyraz szacunku dla wszystkich, w tym polskich ofiar nazizmu, a także memento wobec tych, a jest ich niemało, którzy nie wierzą, że historia magistra vitae est (historia jest nauczycielką życia)” [s. 65-66]. Współczesny czytelnik Mein Kampf ma poznać „niebezpieczne absurdy hitlerowskiego programu przebudowy świata, a także określić punkty oznaczające początek drogi, która doprowadziła narodowych socjalistów, a wraz z nimi całe Niemcy, do zbrodni i zagłady" [s. 66].
Krytyczne wydanie Mein Kampf, obnażając mechanizm budowy państwa totalitarnego, stanowi więc przestrogę przed zagrożeniami, które wiążą się z odrzuceniem reguł demokratycznych.

$\mathrm{Na}$ koniec kilka słów o warsztacie naukowym omawianej publikacji. Za podstawę tłumaczenia i opracowania krytycznego zostało przyjęte przez profesora Króla wydanie Mein Kampf z 1942 roku. Swoistą „wizytówką” prezentowanej książki jest aparat naukowy/krytyczny, który należy uznać za godny podziwu i szacunku. Składa się na niego przede wszystkim prawie dwa tysiące przypisów zawierających informacje faktograficzne, komentarze umożliwiające czytelnikowi zrozumienie kontekstu historycznego i politycznego całości tekstu oraz wskazówki dotyczące kierunków dalszych poszukiwań badawczych. Profesor Król demaskuje w nich także stylistyczne manipulacje stosowane przez Hitlera, ponieważ - jak już wyżej wspomniano jest to tekst o dość marnej jakości literackiej i czasami nie sposób jednoznacznie wskazać, co autor ma na myśli. Treści zamieszczone w przypisach są bardzo rzeczowe, ich autor unika ferowania wyroków i wyciągania daleko idących, kategorycznych wniosków. Częścią aparatu naukowego jest także zestawienie bibliograficzne („Bibliografia selektywna”) zawierające wykaz materiałów, zarówno źródeł, jak i literatury, które posłużyły do konstruowania przypisów. Uznanie budzi skala podjętych przez profesora Króla poszukiwań bibliograficznych oraz różnorodność wykorzystanych materiałów. Wszystko to świadczy o tym, jak doskonale poradził on sobie $\mathrm{z}$ obszerną i trudną materią, którą jest dzieło Hitlera.

Dzieło Hitlera jest symbolem zbrodniczych idei, które doprowadziły do śmierci milionów ludzkich istnień, więc nie należy się dziwić, że jego upowszechnianie 
może wzbudzać kontrowersje. Faktem jest jednak, że współcześnie, w dobie Internetu i różnorakich możliwości komunikacyjnych, różne wersje Mein Kampf są ogólnodostępne. Warto więc zapytać: Po co nam krytyczne wydanie Mein Kampf w przekładzie i opracowaniu profesora Eugeniusza Cezarego Króla? Co można wynieść z lektury tej książki? Oczywiście nie sposób zakwestionować korzyści poznawczych omawianej publikacji, ponieważ jest to jedno z najważniejszych źródeł do dziejów narodowego socjalizmu. Poza funkcją poznawczą, to pierwsze w Polsce krytyczne wydanie Mein Kampf pełni także funkcję, którą można nazwać moralną. Uważna lektura tego wydania Mein Kampf pozwala poznać i zrozumieć zagrożenia prowadzące do demontażu systemu demokratycznego oraz skłania do wniosku, że nie wolno ignorować nawet najbardziej niedorzecznych i - zdawałoby się - oderwanych od rzeczywistości idei politycznych. Wszak Hitler otwarcie napisał w Mein Kampf o swoich politycznych planach i ambicjach, ale nikt nie potraktował ich poważnie. W mojej opinii przygotowana przez profesora Króla krytyczna edycja Mein Kampf z pewnością nie zasługuje na potępienie. Co więcej, uważam, że realizatorowi tego arcytrudnego zadania należy się wdzięczność za ogrom- ną pracę, którą wykonał. Przesłaniem tak przygotowanego wydania Mein Kampf nie jest na pewno propaganda nienawiści i apologia nazizmu. Wręcz przeciwnie - profesor Król demaskuje absurdy, o których pisał Hitler, i zarazem skłania do głębszej refleksji nad aktualną kondycją demokracji, żeby faszyzm i nacjonalizm nie stały się atrakcyjnymi ideologiami.

\section{Bibliografia:}

Goebbels, J. (2014). Dzienniki. E.C. Król (oprac.). T. 1: 1923-1939; t. 2: 1939-1943, Warszawa 2013; t. 3: 1943-1945, Warszawa 2014.

Hartmann, Ch., Vordermayer, Th., Plöckinger, O., Töppel, R. (red.). (2016). Hitler, Mein Kampf. Eine kritische Edition. T. 1-2. München-Berlin: Institut für Zeitgeschichte.

Król, E.C. (1999). Propaganda i indoktrynacja narodowego socjalizmu w Niemczech 1919-1945. Studium organizacji, treści, metod $i$ technik masowego oddziatywania. Warszawa: Instytut Studiów Politycznych Polskiej Akademii Nauk.

Król, E.C. (2006). Polska i Polacy w propagandzie narodowego socjalizmu $w$ Niemczech 1919-1945. Warszawa: Oficyna Wydawnicza RYTM. 